\title{
АГРАРНА ОСВІТА В КОНТЕКСТІ РЕФОРМУВАННЯ ВИЩОЇ ШКОЛИ УКРӒ̈НИ: СУЧАСНІ ВИКЛИКИ ТА ТЕНДЕНЦІЇ В АГРАРНОМУ СЕКТОРІ
}

https://doi.org/10.37472/2707-305X-2021-3-2-17-3

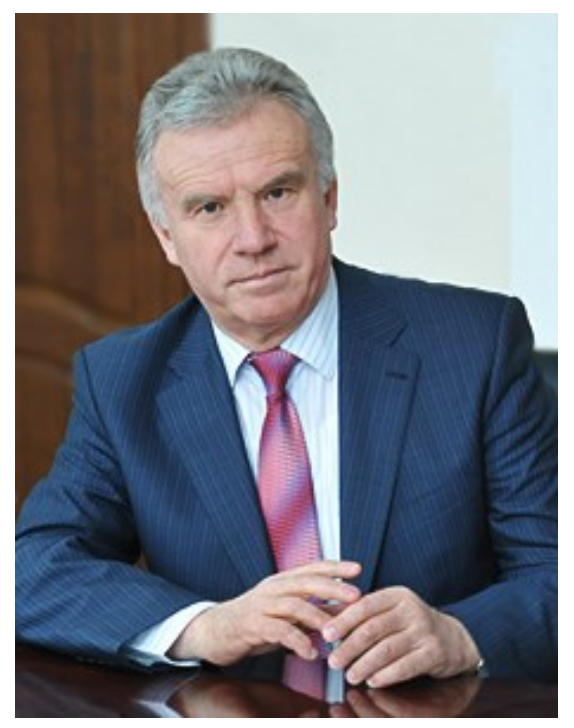
НІКОЛАЄНКО Станіслав Миколайович
доктор педагогічних наук, професор, дійсний член (академік) НАПН України, ректор Національного університету біоресурсів і природокористування України, м. Київ, Україна

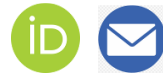

НІКОЛАЕНКО

Микола Станіславович

доктор філософрії, старший викладач кафедри технології м'ясних, рибних та морепродуктів Національного університету біоресурсів і природокористування України, м. Київ, Україна

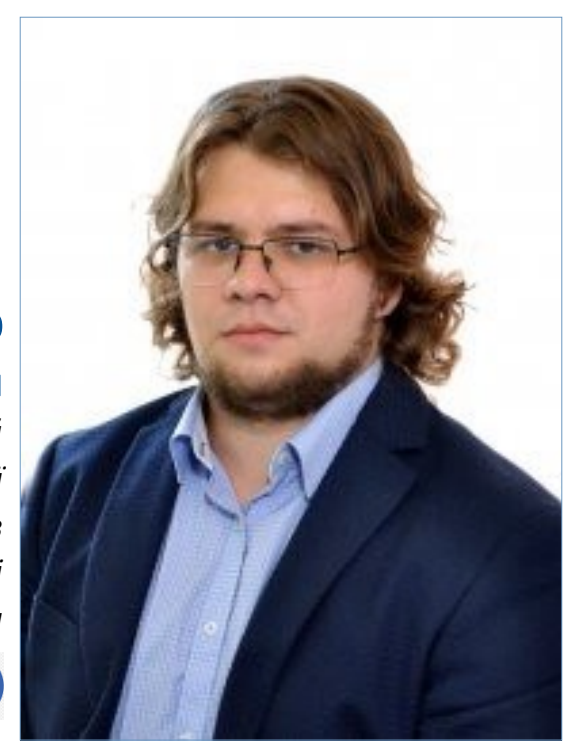

Анотація. У статmі представлено динаміку розвитку аграрної освіти в Україні за останні десять років, зокрема після входження їі до сфери управління Міністерства освіти і науки України в 2015 році. Охарактеризовано зміни в освітньому середовищі та дослідницьких процесах, стан якості освітнього прочесу, основні тендениії в забезпеченні кваліфрікованими кадрами економіки, вплив пандемії на освітній прочес, демографічні зміни, деякі реформи в Україні. Проаналізовано функціонування ринку підготовки кадрів за основними галузями аграрного сектору - рослинництво, тваринництво, лісове господарство; інженерний, енергетичний, інформачійний складники; ситуації з науково-педагогічними кадрами. Розглянуто стан агробіологічної освіти, тенденції їі розвитку, описано окремі існуючі виклики та проблеми, запропоновано основні шляхи розвитку, співпраці з бізнесом, способи подолання наявних перешкод. Наголошено на пріоритетності вдосконалення якості освітнього процесу та практичної підготовки студентів через підвищення ролі бізнесу в житті університетів. Констатовано, що громадськості спільно з народними депутатами України доцільно внести пропозиції щодо законодавчого стимулювання витрат на підготовку кадрів та проведення науково-дослідної роботи, а також варто дозволити підприємиям зараховувати до валових витрат затрати на підтримку університетів і коледжів. Обгрунтовано потребу вдосконалення системи державного замовлення, яка повинна працювати з ретельним аналізом реального сектору економіки, враховуючи міжнародний ринок праці, та забезпечувати конститучійні права громадян на якісну освіту. Наведений аналіз та пропозиції можуть бути корисними для всіх закладів освіти, оскільки мають узагальнений характер і потребують адекватної реакції всього суспільства, уряду, парламенту, науковців, громадськості.

Ключові слова: аграрний сектор; якість освітнього процесу; держзамовлення; дистанційна освіта; потреба в кадрах; ринок праці; співпрачя з бізнесом. 
Сучасний світ mа місце в ньому освіти і науки. Основним наслідком глобалізації в економічному й суспільному розвитку України є ії широка інтеграція до світової економіки з урахуванням тенденцій міжнародного розподілу ринку праці, міграції капіталу, людських та виробничих ресурсів, а також кризових явищ, викликаних пандемією. У таких умовах особливо гостро постає питання потреби в кваліфікованих працівниках, гармонізації ринку праці й освітянських послуг. Виникає ситуація надмірної підготовки кадрів із певних спеціальностей. Водночас окремі напрями, галузі економіки мають проблеми із заповненням вакансій. Як наслідок, на ринку праці маємо кваліфікаційну «яму» (skills mismatch), коли компетенції працівників або надлишкові, або недостатні для виконуваної роботи (Державний університет комунікацій, 2019), тому підвищення якості людського капіталу й ефективне його використання 3 урахуванням не тільки потреб України, а й світу, $\epsilon$ одним з головних завдань країни.

Як стверджує ізраїльський вчений-історик Ювал Ной Харарі (Yuval Noah Harari), нині всесвіт стоїть перед революційними змінам - злиттям дох могутніх цивілізаційних потоків. 3 одного боку, біологи розшифровують генетичні таємниці, з іншого - вчені-комп'ютерники дають нам безпрецедентну швидкість обробки даних. Країни, що опанують штучний інтелект, будуть на чолі прогресу. Країни, що не зможуть цього зробити, стануть назавжди «відсталими» (Харарі, 2018). Сценарії майбутнього розвитку світу схематично подано на рис. 1. Народи, нації, їхні уряди, які не усвідомлюють значення розвитку освіти, науки, технологій, можуть бути викинуті за межі цивілізації.

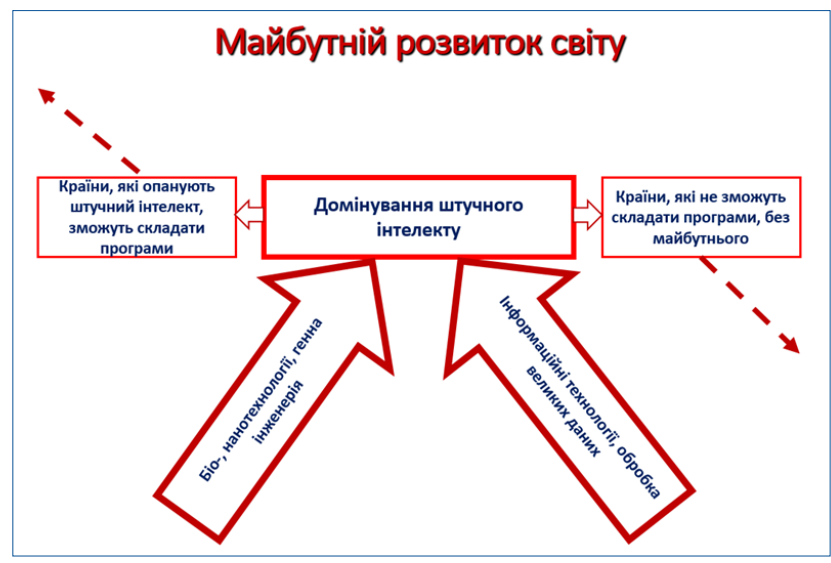

Рис. 1. Сценарії розвитку світу за Ю.Н. Харарі

Тим більше, що світ стоїть не тільки перед загрозами пандемії, а ще й екологічною кризою.
Білл Гейтс (William Henry 'Bill' Gates III) у своїй книзі «Як відвернути кліматичну катастрофу» говорить про сучасні глобальні завдання для людства - не допустити руйнівних наслідків зміни клімату, припинити викидання парникових газів в атмосферу. Тому нове покоління вчених, екологів, фахівців з аграрної, переробної сфери мусить «розробити серйозні плани для досягнення нульових викидів в атмосферу, відвернути катастрофу» (Ґейтс, 2021).

За висновками Гейтса, найближчим часом поряд із завданням збільшення на 70 \% їжі потрібно скорочувати парникові викиди з 51 млрд тонн на рік аж до нуля. Для цього буде потрібна величезна кількість інновацій, а отже, і гарно підготовлені, сучасні кадри.

Характеристика системи аграрної освіти в Україні. Для визначення тенденцій на ринку освітянських послуг та визначення шляхів гармонізації з ринком праці ми провели короткий ретроспективний аналіз за минуле десятиліття підготовки фахівців у закладах аграрної вищої та фахової передвищої освіти.

Зауважимо, що соціально-економічна криза в Україні, війна на Сході, анексія Криму, пандемія та демографічна криза відобразилися і на вищій освіті держави.

Сьогодні в силу об'єктивних причин аграрний сектор є провідним в економіці країни, забезпечуючи 17 \% ВВП та 40 \% валютних надходжень. У сільському господарстві функціонують майже 56,5 тис. суб'єктів господарювання, 3 них 39 тис. фермерських господарств. Вони використовують 21,6 млн га сільськогосподарських угідь, із них фермерські господарства - 4,3 млн га. У власності агробізнесу перебувають основні засоби вартістю понад 100 млрд грн.

Кількість сільських населених пунктів в Україні складає 28,5 тис., а чисельність сільського населення - 14 млн осіб. У виробництві сільськогосподарської продукції зайнято понад 3 млн населення держави, а кількість домогосподарств в Україні складає 17 млн. У виробництві сільськогосподарської продукції зайнято приблизно 2,6 млн осіб, зокрема на сільськогосподарських підприємствах - 460 тис. осіб.

В Україні діє 21 заклад вищої освіти (зокрема, 3 інститути в структурі закладів вищої освіти) та 104 коледжі, які готують кадри для аграрного сектору за 59 бакалаврськими та 47 магістерськими програмами. 
Зазначимо, що з 2010 року загальний контингент студентів в усіх університетах, академіях та інститутах України зменшився майже вдвічі: 3 2067 тис. осіб до 1082 тис. осіб (див. рис. 2), у тому числі тих, хто навчався коштом державного бюджету, відповідно на 48 \% (з 799 до 382 тис. осіб).

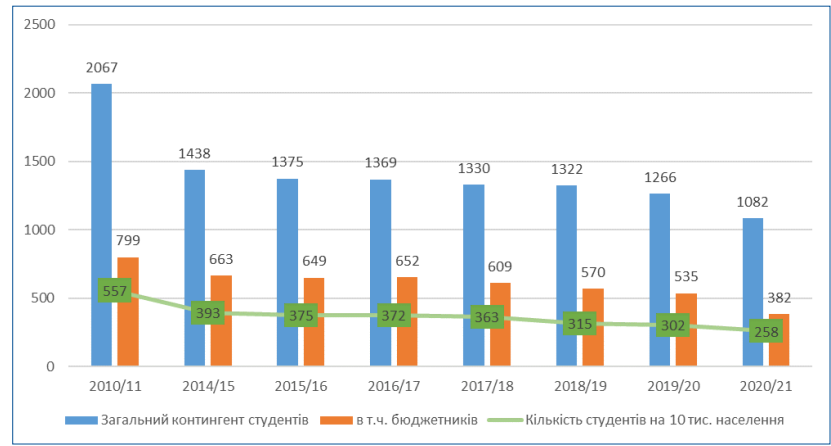

Рис. 2. Динаміка контингенту студентів у зВО України (університети, академії, інститути), тис. осіб

Прикрим є те, що загальна кількість студентів на 10 тис. населення України зменшилася з 557 до 258 особи. Водночас у США та Росії цей показник тримається на рівні 580 та 560 студентів на 10 тис. населення.

Не оминула криза й аграрні заклади освіти. Загальний контингент студентів у них зменшився із 160 тис. осіб у 2010 році до 92,1 тис. осіб у 2020 році, у тому числі тих, хто навчався коштом державного бюджету, відповідно 369 до 38,8 тис. осіб (рис. 3 ).

Водночас загальна кількість студентів на 10 тис. сільського населення України зменшилася із 117 до 70 осіб.

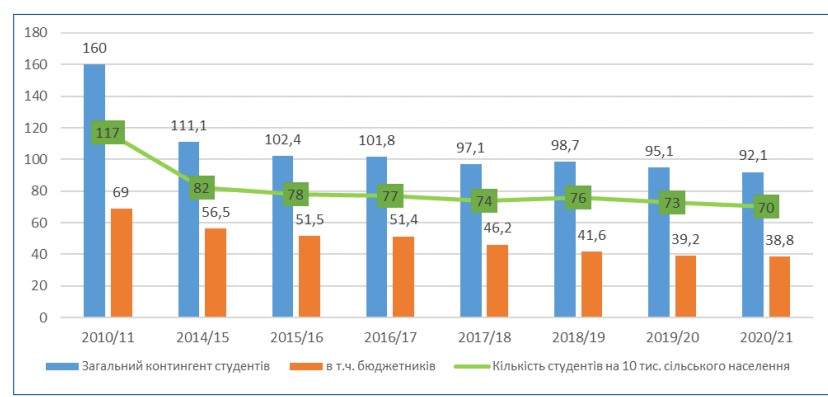

Рис. 3. Динаміка контингенту студентів у аграрних 3ВО (університети, академії, інститути), тис. осіб

На сьогодні із загального контингенту студентів аграрних університетів, академій та інститутів 61,9 тис. осіб (67\%) навчаються на денній і 30,2 тис. осіб (33\%) - на заочній (дистанційній) формах навчання.

На денній формі коштом державного бюджету навчається 32,7 тис. осіб (53\%) і 29,2 тис. осіб (47 \%) - коштом фізичних та юридичних осіб.

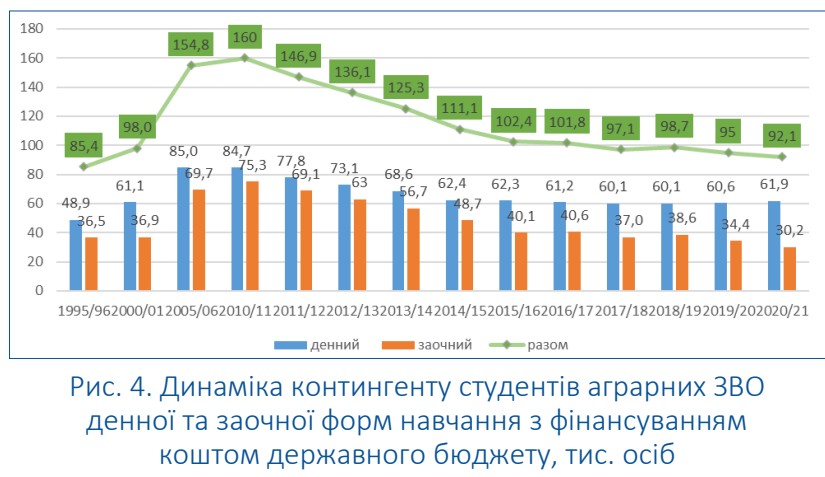

На заочній формі навчання коштом державного бюджету всього навчається 6,1 тис. осіб (20\%) і 24,1 тис. осіб (80 \%) - коштом фізичних та юридичних осіб.

Розподіл контингенту студентів по кожному закладу освіти наведено на рис. 5.

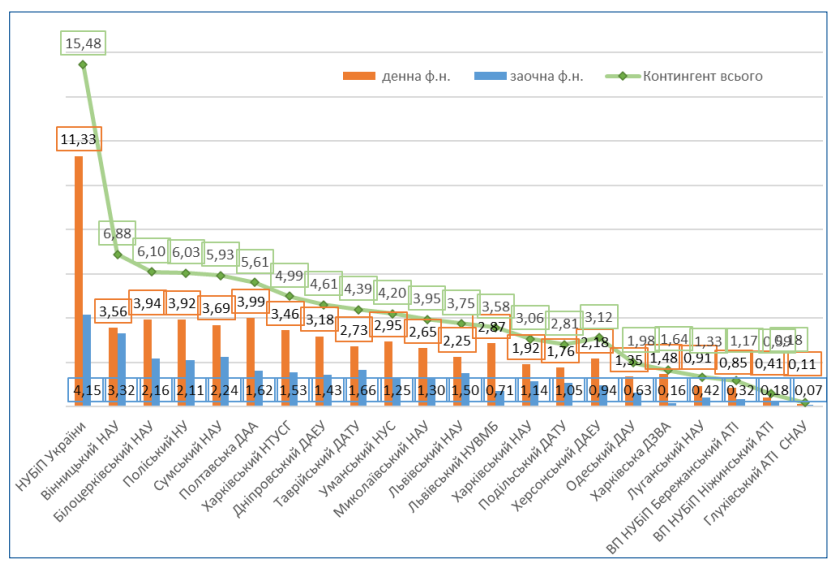

Рис. 5. Контингент студентів у розрізі аграрних закладів вищої освіти за формами навчання всіх джерел фінансування, тис. осіб

Водночас мусимо констатувати, що входження аграрних закладів освіти 2015 року до складу Міністерства освіти і науки України має як позитивні, так і негативні наслідки, зокрема спрощено порядок акредитації та ліцензування спеціальностей, отримання наукових ступенів, вчених звань, друкування наукових статей, відновилася науково-дослідна робота. Проте на тлі загальної кризи дещо погіршилося фінансування закладів освіти, їх утримання. Невирішеними досі $€$ проблеми оподаткування виробництва, оформлення земель, майнових комплексів.

Певні тривожні тенденції спостерігаються і в професійних коледжах. В аграрних коледжах і технікумах загальний контингент студентів скоротився відповідно з 87,2 тис. осіб до 51,2 тис. осіб, у тому числі коштом державного бюджету із 58,5 до 40,6 тис. осіб. Загальна кількість студентів коледжів та технікумів за останні 10 років зменшилася з 64 до 39 осіб на 10 тис. сільського населення України. 
Наведений аналіз засвідчує, що загальний контингент студентів аграрних коледжів і технікумів становить понад 51,7 тис. осіб, із них 43,6 тис. осіб (84 \%) навчаються на денній та 8,1 тис. осіб (16 \%) - на заочній формах навчання (рис. 6 та 7).

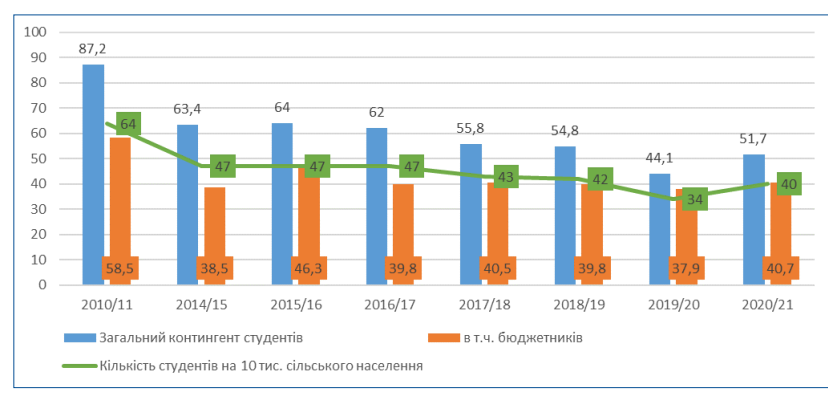

Рис. 6. Динаміка контингенту студентів у аграрних 3 ВО (коледжі, технікуми), тис. осіб

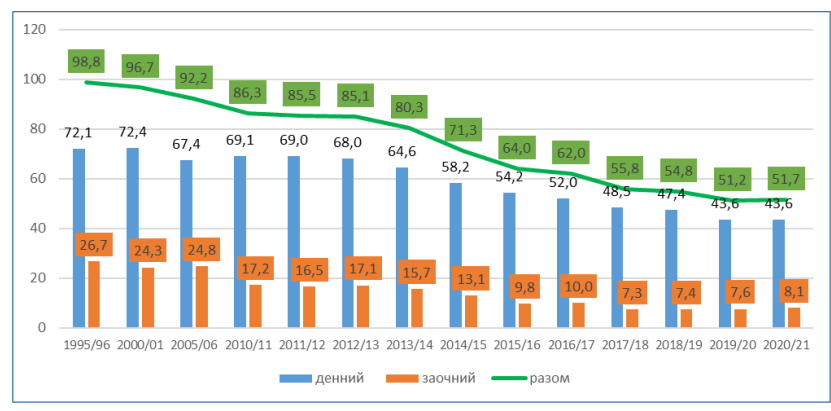

Рис. 7. Динаміка контингенту студентів аграрних коледжів і технікумів за формами навчання всіх джерел фінансування, тис. осіб

Негативно на діяльність коледжів впливають їхня правова невизначеність, передавання їхнього майна місцевим бюджетам, пошук їхнього місця в системі професійної освіти, намагання окремих законодавців об'єднати їх із профтехучилищами.

Як бачимо, загальний контингент студентів, а також контингенти студентів денної та заочної форм навчання коштом державного бюджету та фізичних і юридичних осіб аграрних закладів вищої та фахової передвищої освіти стабільно зменшується, починаючи з 2010 року.

Аналіз обсягів зарахування вступників на денну форму навчання показує, що за профільними аграрними спеціальностями обсяги прийому студентів на початковий цикл навчання коштом державного бюджету мають також тенденцію до стабільного падіння (рис. 8). Так, прийом бакалаврів зі спеціальності «Агрономія» 2010 року становив 2167 осіб, 2015 року - 1266 осіб, а 2020 року 1095 осіб, що майже вдвічі менше, ніж 2010 року, і на 171 особу менше, ніж у 2015 році. Прийом студентів ОС «Молодший спеціаліст» аналогічно зменшено з 1583 осіб у 2010 році до 1362 осіб у 2020 році.

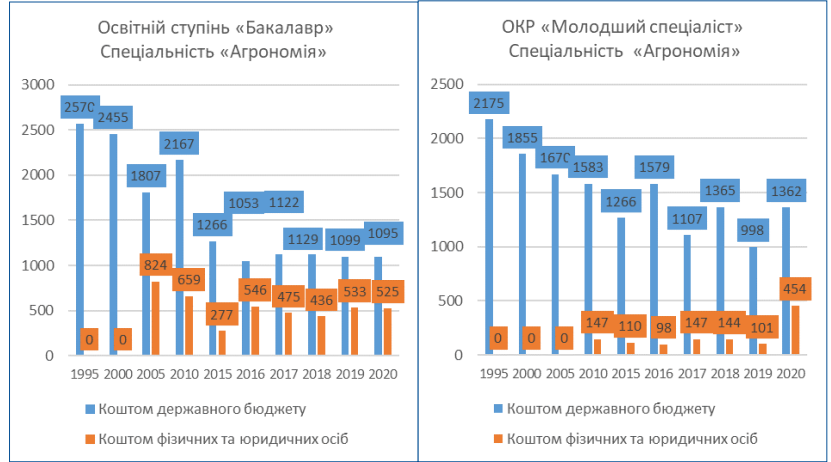

Рис. 8. Динаміка зарахування студентів на денну форму навчання зі спеціальності «Агрономія», осіб

На контингент студентів аграрних коледжів негативно вплинуло не зовсім виважене рішення законодавців про вступ випускників до 3 ВО після закінчення коледжу на основі двох обов'язкових ЗНО. Цей крок змушує педагогічні колективи переглядати навчальні плані і програми, скорочувати професійні складники, збільшуючи загальноосвітні, відмовляючись від спеціалізованих курсів фізика для агронома, хімія для харчовика і т. ін.

Зазначимо, що зменшення підготовки спеціалістів-агрономів відбувається на тлі значного зростання виробництва зернових та зернобобових культур, запровадження складних органічних технологій, точного (прецизійного) землеробства. Валове виробництво зернових склало в 1995 році 36 млн т, а 2020 року - 65,4 млн т.

Стабільний спад відбувається і в прийомі на навчання фахівців для галузі тваринництва (рис. 9). Так, обсяги прийому до ЗВО ветеринарів скоротилися з 1527 осіб у 2010 році до 1083 осіб у 2015 році і до 1026 осіб у 2020 році. Відповідно і прийом до коледжів і технікумів скоротився 3 1564 осіб до 1287 осіб і 945 осіб.

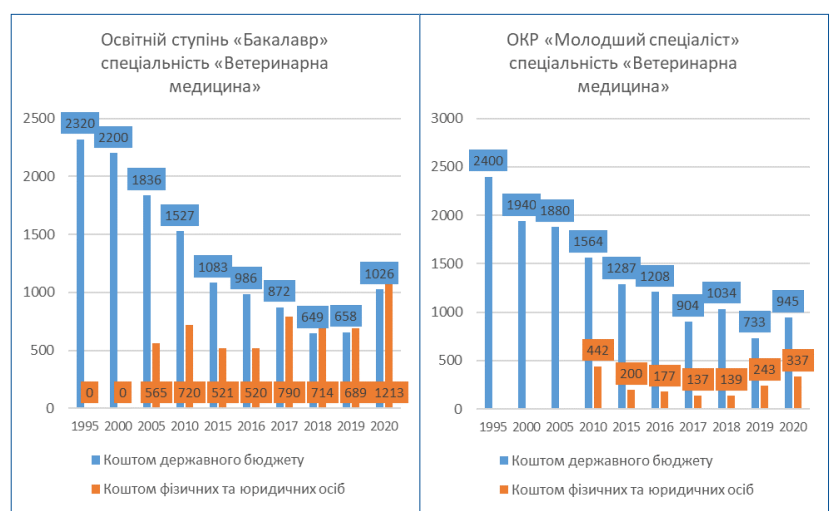

Рис. 9. Динаміка зарахування студентів на денну форму навчання зі спеціальності «Ветеринарна медицина», осіб

Аналогічною є ситуація з підготовкою технологів тваринницької галузі (рис. 10). Зі спеціальності «Технологія виробництва і переробки продукції 
тваринництва» втричі зменшено відповідний набір на бакалаврів і вдвічі - на «Молодшого спеціаліста» (молодшого фахового бакалавра).

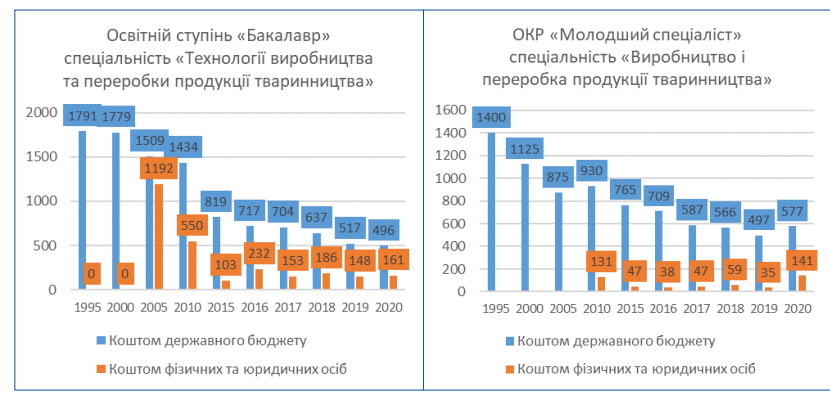

Рис. 10. Динаміка зарахування студентів на денну форму навчання зі спеціальності «Технології виробництва та переробки продукції тваринництва», осіб

Змушені також констатувати, що зменшився обсяг прийому за державним замовленням освітнього ступеня «Бакалавр» за спеціальністю «Агроінженерія» (рис. 11). Тут скорочення відбулося у 2015 році на 830 осіб порівняно з 2010 роком і на 769 осіб у 2020 році порівняно з 2010 роком. Прийом до коледжів і технікумів майже стабільний, але має також тенденцію до падіння.

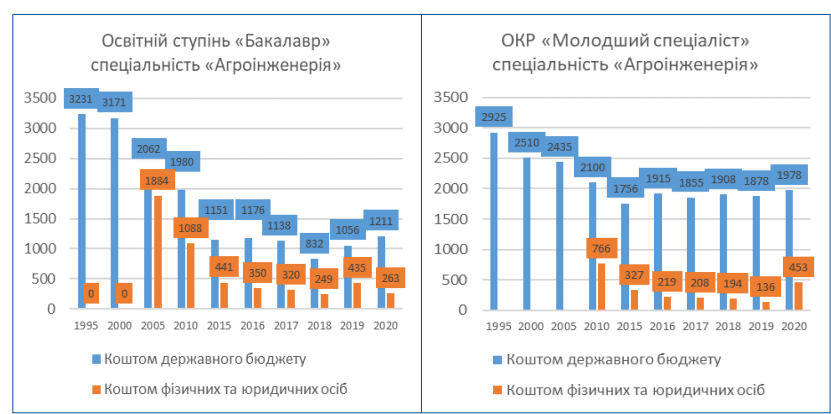

Рис. 11. Динаміка зарахування студентів на денну форму навчання зі спеціальності «Агроінженерія», осіб

Аналіз діяльності аграрних закладів освіти говорить про добре напрацьовану систему їхньої взаємодії, узгодження навчальних планів та програм. Добре себе зарекомендувала ступенева форма підготовки кадрів в аграрних закладах освіти, яку започаткували ще двадцять років тому. Випускники коледжів за обраною спеціальністю успішно продовжують навчання у профільних ЗВО, економлячи в рік до одного мільярда гривень бюджетних коштів (рис. 12, 13).

Тому законодавцям слід внести зміни до Закону України «Про вищу освіту» і передбачити продовження навчання випускників коледжів у закладах вищої освіти не через вступ, як це роблять школярі, а через професійний відбір (можливо, і через тестування), адже студенти коледжів не вступають на перший курс, а продовжують навчання на

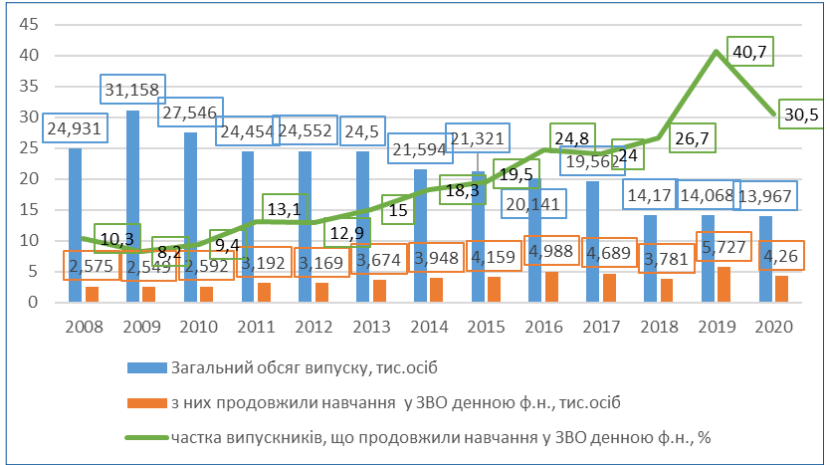

Рис. 12. Динаміка загальних обсягів випуску фахівцівпочатківців ОКР «Молодший спеціаліст» та реалізація ступеневої освіти

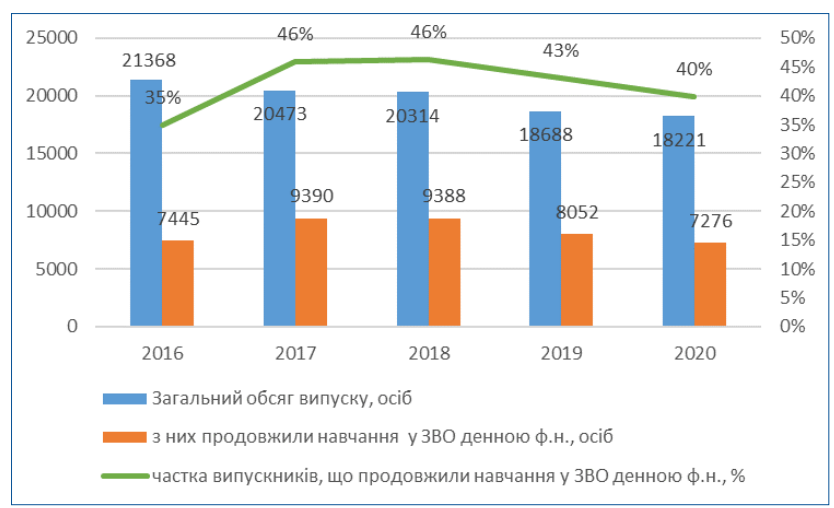

Рис. 13. Динаміка загальних обсягів випуску

ОС «Бакалавр» та реалізація ступеневої освіти

2-3 курсі за спеціальностями 2-3-річних бакалаврських програм.

На нашу думку, не витримує критики і питання про те, навіщо всі бакалаври вступають до магістратури. Насправді таких у минулому році виявилося не більше 40 \% (рис. 14).

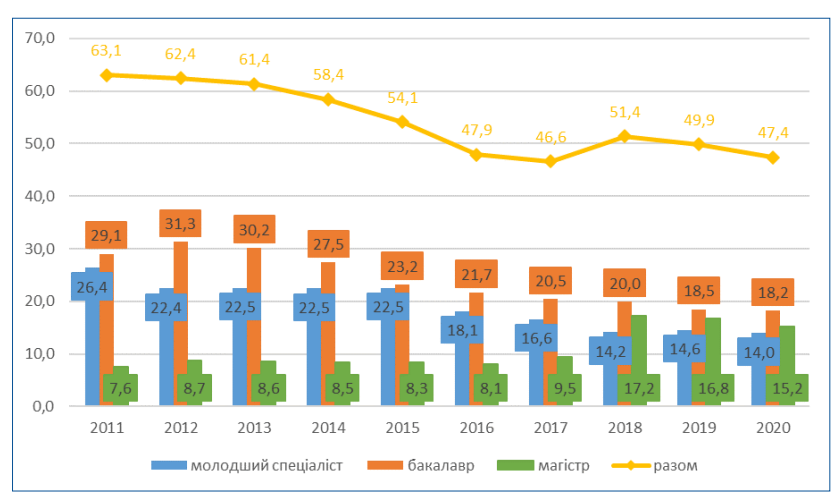

Рис. 14. Динаміка випуску фахівців денної та заочної форм навчання всіх джерел фінансування, тис. осіб

Загальний випуск молодших спеціалістів 13967 осіб, у тому числі 11512 осіб за денною формою навчання, з яких 9862 осіб навчалися коштом державного бюджету, та 2455 осіб заочної форми навчання, з яких 1249 осіб навчалися коштом державного бюджету. 
Система ступеневої підготовки надає широкі можливості для задоволення освітніх потреб людини, підвищує гнучкість та всебічність підготовки фахівців, рівень їхнього соціального захисту відповідно до економічних змін та потреб ринку праці, забезпечує здобуття бажаної кваліфікації або ії підвищення за обраним напрямом професійного спрямування.

Загальні обсяги випуску фахівців в аграрних закладах освіти з повною вищою освітою 2020 року становили 15192 особи, у тому числі за денною формою навчання 8192 особи, з яких 4645 осіб навчалися коштом державного бюджету, та 7000 осіб заочної форми навчання, з яких 1180 осіб навчалися коштом державного бюджету.

Аналіз прачевлаштування випускників та nотреба в кадрах для держави. Загальний випуск фахівців освітніх ступенів та освітньокваліфікаційного рівня має стабільну тенденцію до зниження, що відповідає динаміці обсягів прийому вступників.

За даними Державної служби статистики України, середньооблікова кількість штатних працівників у квітні 2021 року в сільському, лісовому та рибному господарствах становить 401,1 тис. осіб, а заробітна плата - 12,5 тис. гривень (Державна служба статистики України, 2021).

Кількість безробітних в Україні, зареєстрованих в Державній службі зайнятості, становить 379 тис. осіб, у тому числі в сільському, лісовому та рибному господарствах - 36,4 тис. осіб. Кількість вакансій, зареєстрованих у Державній службі зайнятості, становить 69 тис., у тому числі в сільському, лісовому та рибному господарствах - 5,7 тис. вакансій, що становить 6 осіб на одну вакансію.

Кількість безробітних з-поміж осіб, які впродовж року з дня закінчення закладів вищої освіти зареєструвалися в державній службі зайнятості, у
2019 році становила 9560 осіб, із них з повною вищою освітою - 2889 осіб, незакінченою вищою освітою - 2691 особа, фахівців-початківців 3941 особа та тих, хто має професію, - 39 осіб.

Ми також проаналізували працевлаштування випускників, зокрема зі спеціальності 211 «Ветеринарна медицина» з повною вищою освітою. Випуск ветеринарних лікарів 2020 року склав 951 особу, що становить 6 \% від загального випуску фахівців в аграрних університетах. Аналіз свідчить, що 83 \% випускників працевлаштувалися за фахом, а саме: 50 \% (482 ос.) - у комерційних установах, 27 \% (257 ос.) - державних органах, 3 \% (27 ос.) - продовжили навчання (наука), 2 \% (22 ос.) - виїхали за кордон; майже 1 \% (6 ос.) - залучені до науково-педагогічної діяльності. При цьому лише 17 \% (157 ос.) працевлаштувалися не за фахом.

Спільно з науковцями Національного університету біоресурсів і природокористування України, Українським клубом аграрного бізнесу, Асоціацією «Украгроосвіта» ми проаналізували ситуацію на ринку праці, потребу в основних галузях АПК та чисельність студентів, що навчаються за цими спеціальностями.

Забезпеченість професійними кадрами фахівців з харчових технологій, лісового господарства, галузевого машинобудування, автоматизації АПК коливається від 7 \% до $30 \%$.

Крім того, спільно з Громадською Радою освітян і науковців України проаналізовано вступ до магістратури за основними педагогічними спеціальностями (табл. 1). 3’ясовано, що на 15 тис. діючих шкіл в Україні буде готуватися вкрай мізерна кількість магістрів з хімії, біології, фізики чи математики. На цю тенденцію оперативно мусить відреагувати уряд, місцева влада. Напевно, осторонь цих процесів не повинна стояти і Національна академія педагогічних наук України.

Таблиия 1

Аналіз складання $Є B \mathrm{~B}$ в педагогічних університетах за окремими спеціальностями, 2021 р.

\begin{tabular}{|c|c|c|c|c|c|c|c|}
\hline \multirow{2}{*}{ Спеціальність } & \multirow{2}{*}{ Спеціалізація } & \multirow{2}{*}{$\begin{array}{c}\text { Кількість } \\
\text { випускників } \\
\text { бакалаврату }\end{array}$} & \multirow{2}{*}{$\begin{array}{c}3 \text { них } \\
\text { зареєстро- } \\
\text { ваних на } \\
€ B \mathrm{\epsilon} \text { ЄВВ }\end{array}$} & \multirow{2}{*}{$\begin{array}{l}\text { Кількість } \\
\text { осіб }\end{array}$} & \multirow{2}{*}{$\begin{array}{c}\text { Кількість осіб, } \\
\text { які успішно } \\
\text { склали (100 або } \\
\text { більше балів) } \\
\text { ЄВІ/ЄФВВ }\end{array}$} & \multicolumn{2}{|c|}{$\%$} \\
\hline & & & & & & $\begin{array}{l}\text { тих, хто } \\
\text { складав }\end{array}$ & випуску \\
\hline $\begin{array}{l}014 \text { Середня } \\
\text { освіта }\end{array}$ & $\begin{array}{l}014.01 \text { Українська } \\
\text { мова і література }\end{array}$ & 3576 & 1090 & 1086 & 664 & $61 \%$ & $19 \%$ \\
\hline $\begin{array}{l}014 \text { Середня } \\
\text { освіта }\end{array}$ & 014.04 Математика & 1352 & 514 & 512 & 289 & $56 \%$ & $21 \%$ \\
\hline $\begin{array}{l}014 \text { Середня } \\
\text { освіта }\end{array}$ & 014.05 Біологія & 1353 & 435 & 434 & 189 & $44 \%$ & $14 \%$ \\
\hline
\end{tabular}


Табличя 1 (продовження)

\begin{tabular}{|c|c|c|c|c|c|c|c|}
\hline \multirow[b]{2}{*}{ Спеціальність } & \multirow[b]{2}{*}{ Спеціалізація } & \multirow[b]{2}{*}{$\begin{array}{c}\text { Кількість } \\
\text { випускників } \\
\text { бакалаврату }\end{array}$} & \multirow{2}{*}{$\begin{array}{c}3 \text { них } \\
\text { зареєстро- } \\
\text { ваних на } \\
\text { ЄВІ/ЄФВВ }\end{array}$} & \multirow[b]{2}{*}{$\begin{array}{l}\text { Кількість } \\
\text { осіб }\end{array}$} & \multirow{2}{*}{$\begin{array}{c}\text { Кількість осіб, } \\
\text { які успішно } \\
\text { склали (100 або } \\
\text { більше балів) } \\
\text { ЄВІ/ЄФВВ }\end{array}$} & \multicolumn{2}{|c|}{$\%$} \\
\hline & & & & & & $\begin{array}{l}\text { тих, хто } \\
\text { складав }\end{array}$ & випуску \\
\hline $\begin{array}{l}014 \text { Середня } \\
\text { освіта }\end{array}$ & $\begin{array}{l}014.05 \text { Біологія та } \\
\text { здоров'я людини }\end{array}$ & 231 & 97 & 97 & 38 & $39 \%$ & $16 \%$ \\
\hline $\begin{array}{l}014 \text { Середня } \\
\text { освіта }\end{array}$ & 014.06 Хімія & 388 & 131 & 131 & 62 & $47 \%$ & $16 \%$ \\
\hline $\begin{array}{l}014 \text { Середня } \\
\text { освіта }\end{array}$ & 014.08 Фізика & 551 & 202 & 202 & 111 & $55 \%$ & $20 \%$ \\
\hline 091 Біологія & - & 2395 & 708 & 707 & 449 & $64 \%$ & $19 \%$ \\
\hline 102 Хімія & - & 799 & 315 & 315 & 254 & $81 \%$ & $32 \%$ \\
\hline $\begin{array}{l}104 \text { Фізика та } \\
\text { астрономія }\end{array}$ & - & 410 & 168 & 167 & 143 & $86 \%$ & $35 \%$ \\
\hline 111 Математика & - & 467 & 210 & 210 & 174 & $82 \%$ & $37 \%$ \\
\hline & Усього & 11522 & 3870 & 3861 & 2373 & $62 \%$ & $21 \%$ \\
\hline
\end{tabular}

Ми також проаналізували, як вплинуло чергове обмеження під час вступу, зокрема введення єдиного вступного випробування з іноземної мови на вступ до магістратури (табл. 2). Як бачимо, ситуація непроста, навіть катастрофічна. Про це ми доповідали на засіданні Ради з аграрної освіти при Міністерстві освіти і науки України 19 липня 2021 року (МОН України, 2021).
Ми свідомі того, що сучасне виробництво вимагає знання іноземної мови. Проте лише наказами та директивними методами успіху не досяпи. Потрібна системна робота щодо вивчення іноземної мови в Україні, починаючи з дитсадка, школи, використовуючи соціальні мережі, організовуючи спілкування з носіями мови, поїздки за кордон тощо.

Табличя 2

Аналіз впливу запровадження ЄBI з іноземної мови під час вступу до магістратури

\begin{tabular}{|c|c|c|c|c|c|c|c|}
\hline Код & $\begin{array}{c}\text { Найменування } \\
\text { спеціальності }\end{array}$ & $\begin{array}{c}\text { Випуск } 2021 \\
\text { OC «Бакалавр» }\end{array}$ & $\begin{array}{c}\text { Зареєстровані } \\
\text { на ЄBI } 2021\end{array}$ & $\begin{array}{l}\text { Зареєстровані } \\
\text { до випуску, \% }\end{array}$ & $\begin{array}{c}\text { Подолали } \\
\text { поріг «склав» }\end{array}$ & $\begin{array}{c}\text { Подолали } \\
\text { поріг, \% }\end{array}$ & $\begin{array}{l}\text { Склали до } \\
\text { випуску, \% }\end{array}$ \\
\hline 208 & Агроінженерія & 776 & 570 & $73 \%$ & 179 & $31 \%$ & $23 \%$ \\
\hline 201 & Агрономія & 1569 & 1074 & $68 \%$ & 436 & $41 \%$ & $28 \%$ \\
\hline 202 & $\begin{array}{l}\text { Захист і карантин } \\
\text { рослин }\end{array}$ & 175 & 131 & $75 \%$ & 55 & $42 \%$ & $31 \%$ \\
\hline 203 & $\begin{array}{l}\text { Садівництво та } \\
\text { виноградарство }\end{array}$ & 65 & 62 & $95 \%$ & 28 & $45 \%$ & $43 \%$ \\
\hline 204 & $\begin{array}{l}\text { Технологія } \\
\text { тваринництва }\end{array}$ & 786 & 555 & $71 \%$ & 224 & $40 \%$ & $28 \%$ \\
\hline 205 & $\begin{array}{l}\text { Лісове } \\
\text { господарство }\end{array}$ & 408 & 239 & $59 \%$ & 82 & $34 \%$ & $20 \%$ \\
\hline 206 & $\begin{array}{l}\text { Садово-паркове } \\
\text { господарство }\end{array}$ & 223 & 128 & $57 \%$ & 41 & $32 \%$ & $18 \%$ \\
\hline 207 & $\begin{array}{l}\text { Водні біоресурси } \\
\text { та аквакультура }\end{array}$ & 183 & 123 & $67 \%$ & 50 & $41 \%$ & $27 \%$ \\
\hline 211 & $\begin{array}{l}\text { Ветеринарна } \\
\text { медицина }\end{array}$ & 465 & 332 & $71 \%$ & 166 & $50 \%$ & $36 \%$ \\
\hline 181 & Харчові технології & 575 & 384 & $67 \%$ & 159 & $41 \%$ & $28 \%$ \\
\hline
\end{tabular}


Табличя 2 (продовження)

\begin{tabular}{|c|c|c|c|c|c|c|c|}
\hline Код & $\begin{array}{c}\text { Найменування } \\
\text { спеціальності }\end{array}$ & $\begin{array}{c}\text { Випуск } 2021 \\
\text { ОС «Бакалавр» }\end{array}$ & $\begin{array}{c}\text { Зареєстровані } \\
\text { на ЄBI } 2021\end{array}$ & $\begin{array}{l}\text { Зареєстровані } \\
\text { до випуску, \% }\end{array}$ & $\begin{array}{c}\text { Подолали } \\
\text { поріг «склав» }\end{array}$ & $\begin{array}{c}\text { Подолали } \\
\text { поріг, \% }\end{array}$ & $\begin{array}{l}\text { Склали до } \\
\text { випуску, \% }\end{array}$ \\
\hline 101 & Екологія & 356 & 236 & $66 \%$ & 92 & $39 \%$ & $26 \%$ \\
\hline 103 & Науки про Землю & 10 & 10 & $100 \%$ & 5 & $50 \%$ & $50 \%$ \\
\hline 133 & $\begin{array}{l}\text { Галузеве } \\
\text { машинобудування }\end{array}$ & 283 & 225 & $80 \%$ & 79 & $35 \%$ & $28 \%$ \\
\hline 141 & $\begin{array}{l}\text { Електроенергетика, } \\
\text { електротехніка та } \\
\text { електромеханіка }\end{array}$ & 563 & 413 & $73 \%$ & 159 & $38 \%$ & $28 \%$ \\
\hline 144 & Теплоенергетика & - & - & - & - & - & - \\
\hline 151 & $\begin{array}{l}\text { Автоматизація та } \\
\text { комп'ютерно- } \\
\text { інтегровані } \\
\text { технології }\end{array}$ & 70 & 41 & $59 \%$ & 28 & $68 \%$ & $40 \%$ \\
\hline 161 & $\begin{array}{l}\text { Хімічні технології } \\
\text { та інженерія }\end{array}$ & - & - & - & - & - & - \\
\hline 162 & $\begin{array}{l}\text { Біотехнології та } \\
\text { біоінженерія }\end{array}$ & 78 & 63 & $81 \%$ & 45 & $71 \%$ & $58 \%$ \\
\hline 163 & $\begin{array}{l}\text { Біомедична } \\
\text { інженерія }\end{array}$ & - & - & - & - & - & - \\
\hline 183 & $\begin{array}{l}\text { Технології захисту } \\
\text { навколишнього } \\
\text { середовища }\end{array}$ & 34 & 30 & $88 \%$ & 7 & $23 \%$ & $20 \%$ \\
\hline 187 & $\begin{array}{l}\text { Деревообробні та } \\
\text { меблеві технології }\end{array}$ & 37 & 15 & $41 \%$ & 7 & $47 \%$ & $19 \%$ \\
\hline 192 & $\begin{array}{l}\text { Будівництво та } \\
\text { цивільна } \\
\text { інженерія }\end{array}$ & 360 & 267 & $74 \%$ & 111 & $42 \%$ & $30 \%$ \\
\hline 193 & $\begin{array}{l}\text { Геодезія та } \\
\text { землеустрій }\end{array}$ & 506 & 395 & $78 \%$ & 148 & $37 \%$ & $29 \%$ \\
\hline 194 & $\begin{array}{l}\text { Гідротехнічне } \\
\text { будівництво, } \\
\text { водна інженерія } \\
\text { та водні технології }\end{array}$ & 22 & 22 & $100 \%$ & 6 & $27 \%$ & $27 \%$ \\
\hline 212 & $\begin{array}{l}\text { Ветеринарна } \\
\text { гігієна, санітарія і } \\
\text { експертиза }\end{array}$ & - & - & - & - & - & - \\
\hline 231 & Соціальна робота & 37 & 36 & $97 \%$ & 21 & $58 \%$ & $56 \%$ \\
\hline 241 & $\begin{array}{l}\text { Готельно- } \\
\text { ресторанна } \\
\text { справа }\end{array}$ & 41 & 34 & $83 \%$ & 12 & $35 \%$ & $29 \%$ \\
\hline 242 & Туризм & 125 & 84 & $67 \%$ & 30 & $36 \%$ & $24 \%$ \\
\hline 274 & $\begin{array}{l}\text { Автомобільний } \\
\text { транспорт }\end{array}$ & 103 & 59 & $57 \%$ & 14 & $24 \%$ & $14 \%$ \\
\hline 015 & Професійна освіта & 45 & 40 & $89 \%$ & 20 & $50 \%$ & $44 \%$ \\
\hline 051 & Економіка & 293 & 238 & $81 \%$ & 97 & $41 \%$ & $33 \%$ \\
\hline 071 & $\begin{array}{l}\text { Облік і } \\
\text { оподаткування }\end{array}$ & 1087 & 757 & $70 \%$ & 257 & $34 \%$ & $23 \%$ \\
\hline
\end{tabular}


Таблиця 2 (продовження)

\begin{tabular}{|c|l|c|c|c|c|c|c|}
\hline Код & $\begin{array}{c}\text { Найменування } \\
\text { спеціальності }\end{array}$ & $\begin{array}{c}\text { Випуск 2021 } \\
\text { ОС «Бакалавр» }\end{array}$ & $\begin{array}{c}\text { Зареєстровані } \\
\text { на ЄВІ 2021 }\end{array}$ & $\begin{array}{c}\text { Зареєстровані } \\
\text { до випуску, } \%\end{array}$ & $\begin{array}{c}\text { Подолали } \\
\text { поріг «склав» }\end{array}$ & $\begin{array}{c}\text { Подолали } \\
\text { поріг, \% }\end{array}$ & $\begin{array}{c}\text { Склали до } \\
\text { випуску, \% }\end{array}$ \\
\hline $\begin{array}{l}\text { банківська справа } \\
\text { та страхування }\end{array}$ & 647 & 448 & $69 \%$ & 185 & $41 \%$ & $29 \%$ \\
\hline 073 & Менеджмент & 812 & 588 & $72 \%$ & 255 & $43 \%$ & $31 \%$ \\
\hline 075 & Маркетинг & 212 & $70 \%$ & 103 & $49 \%$ & $34 \%$ \\
\hline $\begin{array}{l}\text { Підприємництво, } \\
\text { торгівля та } \\
\text { біржова діяльність }\end{array}$ & 216 & 156 & $72 \%$ & 50 & $32 \%$ & $23 \%$ \\
\hline $\begin{array}{l}\text { РАЗОм за всіма } \\
\text { спеціальностями }\end{array}$ & 11253 & 7967 & $71 \%$ & 3151 & $40 \%$ & $28 \%$ \\
\hline
\end{tabular}

В університеті студенти вчать фахову, спеціальну термінологію, а іспит $Є B \mathrm{I}$ діагностує загальні знання мови, правила, граматику тощо. Вважаємо, що доцільно було 6 переглянути також зміст вивчення іноземних мов у ЗВО та провести атестацію науково-педагогічних працівників, які викладають іноземну мову. Національний університет біоресурсів і природокористування України запровадив безкоштовні курси з підготовки до складання $\Theta B \mid$ для всіх студентів. I цей досвід варто поширювати

Кадровий склад науково-педагогічних працівників, які працюють в аграрних закладах вищої освіти. Цікавість викликає і проблема кваліфікованості науково-педагогічних працівників аграрних закладів освіти. Підготовку фахівців у них здійснюють 6439 штатних науково-педагогічних працівників, з-поміж яких 5150 (80\%) докторів філософії та докторів наук, 682 (10,6 \%) професорів, 3154 (49,0\%) доцентів, 37 (0,6 \%) старших дослідників.

Аналіз якісного складу науково-педагогічних працівників свідчить, що за останні 15 років на 100 студентів наведеного контингенту кількість докторів наук збільшилася 3 1,0 осіб до 1,3 особи, а кількість докторів філософії - відповідно із 6,2 до 6,7 осіб (рис. 15, 16).

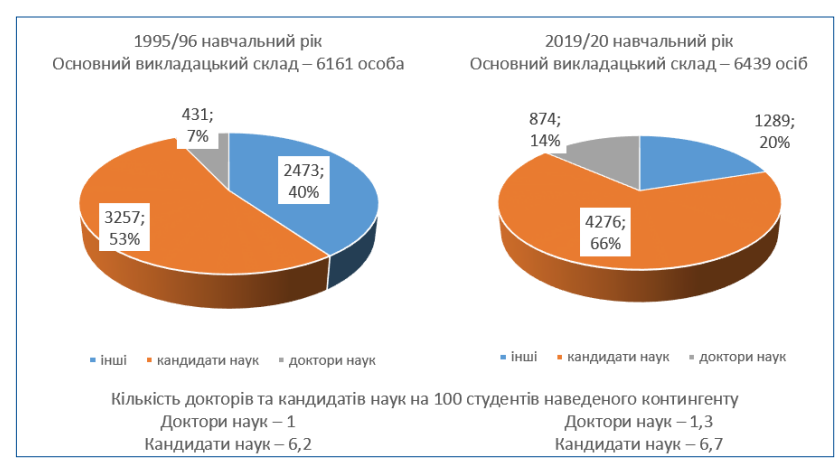

Рис. 15. Якісний склад науково-педагогічних працівників ЗВО за науковими ступенями, осіб / \%

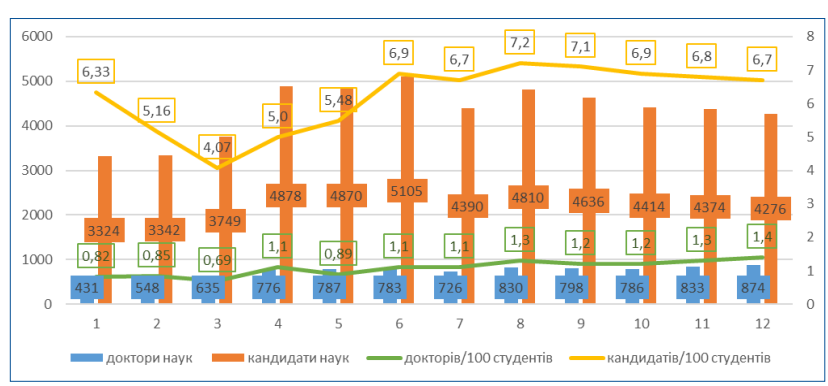

Рис. 16. Динаміка кількості НПП аграрних ЗВО з науковими ступенями із розрахунку на 100 студентів наведеного контингенту, осіб

Аналогічні якісні зміни відбуваються і в складі науково-педагогічних працівників 3 ученими званнями. Так, на 100 студентів наведеного контингенту кількість професорів за аналогічний період збільшилася з однієї особи до 1,1, проте кількість доцентів зменшилася з 5 осіб до 4,9 осіб.

За формальними показниками кадровий склад науково-педагогічних працівників поліпшився. Проте якісний склад, вікові тенденції є критичними. Бачимо певне старіння науково-педагогічних кадрів, небажання талановитої молоді йти на викладацьку роботу, певну відірваність педагогів від реального сектору, застарілу матеріальнотехнічну базу, низький рівень дослідництва, погіршення баз практик.

Гостро назрілою для вирішення є проблема забезпечення житлом науково-педагогічних працівників, унесення змін до законодавства, які б дали змогу закладам вищої освіти вкладати свої кошти в житлове будівництво, використовувати для цих цілей землі, які є у власності освітніх закладів.

Замість висновків - пропозиції щодо поліпшення стану аграрної освіти. Постійне оновлення вищої аграрної освіти, на наш погляд, є безальтернативним. Його мета - якісна освіта, інтегрована в Європейський освітній простір, «конвертований» диплом, забезпечення високотехно- 
логічного та інноваційного розвитку країни, самореалізація особистості, задоволення потреб суспільства, ринку прачі та держави у кваліфікованих фрахівиях.

Шляхи вирішення - пошук і виховання мотивованого студента, кваліфікованого викладача, щедра розумна держава, добре оплачувані робочі місця, системна профорієнтаційна робота, а також створення стимулів для партнерства бізнесу із закладами освіти.

Очікувані результати - розвинута економіка, добробут суспільства, гарантовані права і можливості, процвітання українського села і міста.

Ризики і можливі негативні наслідки - оптимізація (закриття, об'єднання тощо) закладів освіти скорочення бюджетного складника і розширення комерційного, звуження доступу до навчання сільських дітей, деградація соціальної та виробничої сфери, а також втрата робочих місць для науково-педагогічних працівників.

Якщо говорити про можливі економічні досягнення країни, рівень життя, демографічну ситуацію, міграцію населення, розглядаючи це зокрема і як результат освітянської діяльності з підготовки кадрів, то матимемо поки що невтішний результат, який не потребує додаткових коментарів.

Ще одне питання, яке ми сором'язливо обходимо, - ринок праці. Не може ринок освітянських послуг бути зорієнтований лише на ринок праці України. Якщо так, то навіщо нам була потрібна Європейська інтеграція, Болонський процес, «конвертований» диплом і європейський досвід запровадження кредитної трансферно-накопичувальної системи, не говорячи вже про знання іноземної мови. Будемо відвертими: стан економічного розвитку країни не передбачає особливого збільшення національного валового продукту, а відповідно і створення нових робочих місць.

Отже, хочемо ми чи не хочемо, але значна кількість молодих людей буде змушена виїжджати за кордон на роботу і працювати там, на жаль, здебільшого не за фахом. А за такої ситуації, напевно, варто реагувати і на потреби світового ринку праці. Час настав думати не тільки про державу, а й про окремо взятого українця, його добробут. Не можна нескінченно скорочувати підготовку фахівців, економити на освіті. Рано чи пізно фахівці знадобляться.

Науково-педагогічну громадськість, аграрний бізнес, учених, роботодавців, студентів хвилює певна заангажованість окремих законодавців, урядовців, репресивний характер реформ у вищій школі. Нам ззовні весь час нав'язують усілякі заборони, обмеження. Ні про яку демократію, автономію закладів вищої освіти не йдеться, коли науково-педагогічні колективи нині практично не впливають на вступ до закладів вищої освіти, а «широкий конкурс» нівелює всю профорієнтаційну роботу. Потрібно зберегти, без сумніву, вступ через зовнішнє незалежне оцінювання (але хай це роблять самі абітурієнти, обираючи «свій» університет); обмежити кількість заяв на вступ (двітри) і не примушувати ціле літо тисячі членів приймальних комісій рахувати сотні тисяч пустих заяв абітурієнтів, а в кінці отримати від усього цього процесу «пшик». За «широкого конкурсу» абітурієнт часто-густо після зарахування не приходять туди, куди його зарахував комп'ютер, а заклади вищої освіти залишаються без студентів...

В Україні у зв'язку із земельною реформою $\epsilon$ гостра необхідність унормування земельних питань, тому Міністерству аграрної політики та продовольства України, Державній службі України з питань геодезії, картографії та кадастру спільно з Міністерством освіти і науки України потрібно взяти цю проблему під особливий контроль та провести серію нарад щодо прискорення оформлення земельних актів, недопущення порушень земельного законодавства, вилучення земель у закладів освіти.

Необхідно приділити увагу підвищенню якості освітнього процесу, удосконаленню онлайннавчання, зміцненню матеріально-технічної бази, завершенню процедури створення та оновлення електронних навчальних платформ, широкому застосуванню «змішаного» навчання. Необхідним $€$ вдосконалення наявної бази практик, зокрема перехід від групових до індивідуальних практик. Нагальною є тема фінансової автономії університетів і коледжів, спрощення ведення господарських операцій, посилення зв' язків з академіями, зокрема Національною академією педагогічних наук України та Національною академією аграрних наук України

На нашу думку, Міністерству освіти і науки України варто внести пропозиції щодо спрощення процедури закупівель під час проведення сільськогосподарських, науково-дослідних робіт.

Актуальною є плідна співпраця з міністерством, подолання бюрократичних процедур у діяльності міністерств і відомств, зокрема під час затвердження статутів університетів та коледжів, списання майна, проведення всіляких погоджень тощо. 
Ураховуючи погіршення матеріального стану сільської молоді, доцільним є вивчення питання про відтермінування, а можливо, і перегляд обов'язкового запровадження індикативної вартості навчання на період економічної кризи, пандемії.

Не можна залишати поза увагою гострі проблеми, як-от вжиття невідкладних заходів по боротьбі з пожежами. Народні депутати України повинні ініціювати виділення окремим рядком у бюджеті хоча 61 млрд грн на боротьбу з пожежами, ліквідацію техногенних небезпек.

Звичайно, на першому плані завжди мусить бути підвищення якості освітнього процесу, практичної підготовки студентів, зокрема шляхом підвищення ролі бізнесу в житті університетів. Громадськості спільно з народними депутатами України доцільно внести законодавчі пропозиції щодо стимулювання витрат на підготовку кадрів та проведення науково-дослідної роботи. Було 6 варто дозволити підприємцям зараховувати у валові витрати затрати на підтримку університетів і коледжів.

Тривожною є ситуація із забезпеченням закладів вищої освіти та академічних установ науковопедагогічними кадрами, тому життя вимагає вжити комплексних заходів щодо вирішення кадрових, соціальних проблем, зокрема стимулювати будівництво житла для науково-педагогічних працівників, нових гуртожитків для студентів, аспірантів.

Потребує вдосконалення система державного замовлення, яка повинна працювати на ретельному аналізі реального сектору економіки, враховуючи міжнародний ринок праці, та забезпечувати конституційні права громадян на якісну освіту.

На якість освітнього процесу дуже істотно вплинув карантин, пандемія. Дослідження Програми міжнародного оцінювання студентів (PISA), яка заміряла якість знань, засвідчило, що студенти, які конспектують лекції ручкою, розмірковують разом з професором, набагато краще засвоюють матеріал, ніж коли вони машинально набирають цей текст на комп'ютерах (Мазорчук та ін., 2019). Напевне, ця проблема мусить бути в полі зору і вчених Національної академії педагогічних наук України, зокрема Інституту вищої освіти.

Непростими є соціальні складники, технічні проблеми. Згідно з даними моніторингових опитувань Інституту соціології НАН України за 2020 рік, майже чверть усіх респондентів не користуються інтернетом (Інститут соціології НАН України, 2020).
3 досвіду японців відомо, що із сотень тисяч студентів, які навчалися дистанційно за річними програмами, лише 5-7 \% отримали сертифікати про закінчення навчання (Kang, 2021).

Ці та інші виклики науково-педагогічна громадськість, Міністерство освіти і науки України, уряд, парламент, академії наук мусять враховувати в повсякденному житті. Потрібно посилити якість мереж інтернету, сконцентруватися на побудові соціальних науково-освітніх програм, платформ, створення віртуальних технологій та ін.

Аграрний сектор економіки, природоохоронна, екологічна діяльність потребують реальної уваги і переосмислення, серйозної підтримки як з боку держави, науковців, так і вітчизняного бізнесу.

\section{СПИСОК ВИКОРИСТАНИХ ДЖЕРЕЛ}

Ґейтс, Б. (2021). Як відвернути кліматичну катастрофу. Де ми зараз і що нам робити далі (Ю. Костюк, пер. з англ.). Київ: Лабораторія.

Державна служба статистики України. (2021). Головна. http://www.ukrstat.gov.ua/

Державний університет комунікацій, кафедра комп'ютерних наук. (2019, 10 грудня). Кваліфікаційна яма: проблема підготовки майбутніх фахівців IT ma IKT. https://bit.ly/3BfpT50

Єдина державна електронна база з питань освіти. (2021). Вступна кампанія 2021. Державне підприємство «Інфоресурс». https://vstup.edbo.gov.ua/

Інститут соціології НАН України. (2020). Українське суспільство: моніторинг соціальних змін, (7). Київ: Інститут соціології НАН України. https://bit.ly/3kF2ymD

Мазорчук, М., Вакуленко, Т., Терещенко, В., Бичко, Г., Шумова, К., Раков, С., Горох, В., Ткач, П., Простакова, Ю., \& Кузнєцова, Ю. (2019). Національний звіт за результатами міжнародного дослідження якоcmi освіmи PISA-2018. Український центр оцінювання якості освіти. Київ: УЦОЯО. https://bit.ly/3sYPn3z

Міністерство освіти і науки України. (2021, 19 липня). У МОН відбулося засідання Ради з питань аграрної oсвimu. https://mon.gov.ua/ua/news/u-mon-vidbulosyazasidannya-radi-z-pitan-agrarnoyi-osviti

Степаненко, В.П. (2021). Соціальні наслідки пандемії COVID-19 у контексті суспільної трансформації в Україні: соціологічний підхід : За матеріалами наукової доповіді на засіданні Президії НАН України 14 квітня 2021 року. Вісник Національної академії наук України, (5), 33-46. https://doi.org/10.15407/ visn2021.05.033

Український центр оцінювання якості освіти. (2021). Bступні до магістратури. https://testportal.gov.ua/ yevi-inozemna-yefvv-pravo/

Харарі, Ю.Н. (2018). 21 урок для 21 столітmя (О. Дем'янчук, пер. $з$ англ.). Київ: Форс Україна.

Kang, B. (2021) How the COVID-19 Pandemic is Reshaping the Education Service. In J. Lee, S.H. Han (Eds.), The Future of Service Post-COVID-19 Pandemic, 1 (pp. 15-36). Springer, Singapore. https:// doi.org/10.1007/978-981-33-4126-5_2 


\title{
AGRICULTURAL EDUCATION IN THE CONTEXT OF HIGHER EDUCATION REFORM IN UKRAINE: CURRENT CHALLENGES AND TRENDS IN THE AGRICULTURAL SECTOR
}

\author{
Stanislav Nikolaienko \\ DSc in Pedagogy, Professor, Full Member (Academician) of NAES of Ukraine, Rector, \\ National University of Life and Environmental Sciences of Ukraine, Kyiv, Ukraine \\ Mykola Nikolaienko \\ PhD, Senior Lecturer of the Department of Meat, Fish and Seafood Technologies, \\ National University of Life and Environmental Sciences of Ukraine, Kyiv, Ukraine
}

\begin{abstract}
The dynamics of agricultural education in Ukraine development over the last decade and after joining the Ministry of Education and Science of Ukraine in 2015 are presented in the paper. The changes in the educational and research processes, state of educational process quality, main trends in providing qualified personnel for the economy, pandemic influence on the educational process, demographic changes, some reforms in Ukraine are characterized. The educational services market is analyzed according to main branches of the agricultural sector - crop production, animal husbandry, forestry; engineering, energy, and information components; situation with the academic staff. The state of agrobiological education, its development trends is considered in the paper; some existing challenges and problems are described; the main directions of development, cooperation with business, ways to overcome the existing obstacles are suggested. The priority of improving the quality of the educational process and students' practical training by increasing the role of business in the universities' life is emphasized. The public together with the People's Deputies of Ukraine should make suggestions on the legislative incentives for spending on specialists training and conducting research. The entrepreneurs should be allowed to include the costs for supporting universities and colleges in the gross costs. The need for state order system improvement is grounded; it should work with a thorough review of the real sector of the economy, taking into account the international labor market, and ensure the constitutional rights of citizens to quality education. The given analysis and suggestions can be helpful for all education intuitions as they are generalized and require a proper response from the whole society, government, parliament, researchers, and the public.
\end{abstract}

Keywords: agricultural sector; quality of educational process; state order; distance education; staffing needs; labor market; cooperation with business. 